AperTO - Archivio Istituzionale Open Access dell'Università di Torino

\title{
Typological Diversity Within the Romance Languages
}

\section{This is the author's manuscript}

Original Citation:

\section{Availability:}

This version is available http://hdl.handle.net/2318/1789523

since 2021-06-03T22:17:15Z

Publisher:

Oxford University Press

Published version:

DOI:10.1093/acrefore/9780199384655.013.429

Terms of use:

Open Access

Anyone can freely access the full text of works made available as "Open Access". Works made available under a Creative Commons license can be used according to the terms and conditions of said license. Use of all other works requires consent of the right holder (author or publisher) if not exempted from copyright protection by the applicable law. 


\title{
Typological diversity within the Romance languages
}

\author{
Davide Ricca
}

\section{Summary}

The Romance languages, despite their overall similarity, display interesting internal diversity which can be captured only very partially by looking at the six major standard languages, as typological databases often do. This diversity spans over all the levels of linguistic analysis, from phonology to morphology and syntax. Rather than making a long list of features, with no space to go much beyond their mere mention, the article focusses on just four main areas in a little more detail, trying to develop, if minimally, a discussion on their theoretical and methodological import.

The comparison with the full-world typological background given by the WALS Online shows that the differences within Romance may reach the level of general typological relevance. While this is probably not the case in their rather mainstream segmental phonology, it surely holds regarding nominal pluralization and the syntax of negation, which are both areas where the Romance languages have often distanced themselves quite significantly from their common ancestor, Latin. The morphological marking of nominal plural displays four values out of the seven recorded in WALS, adding a further one unattested there, namely subtraction; the neg ation strategies, although uniformly particle-like, cover all the five values found in WALS concerning linear order. Finally, Romance languages suggest several intriguing issues related with headmarking and dependent-marking constructions, again innovating against the substantially dependent-marking uniformity characteristic of Latin.

Keywords: Romance languages, typology, comparability, diversity, nonstandard languages, phoneme inventories, plural marking, head-marking, negation

\section{Introduction: Four issues of intra-Romance diversity}

It is no mystery that the Romance languages are, on the whole, rather similar to each other, given the relatively short time span separating them from their common ancestor, and the subsequent intense interlinguistic contact which surely contributed in yielding many parallel developments even in those areas where they have significantly moved away from Latin.

However, this undeniable affinity certainly does not yield a picture of dull uniformity. Quite a few relevant features are encoded very diversely within Romance, in all levels of linguistic analysis. Moreover, typological diversity in Romance is much enhanced if one does not limit oneself to taking into account data from the major standard languages. In fact, the latter choice is often made - or at least used to be - for European languages featuring in typological samples and databases, which obviously does not match the situation in other areas of the world, thus introducing a relevant sociolinguistic distortion which - among other things - makes the Romance landscape in typology look much more monotonous than it actually is ${ }^{1}$.

\footnotetext{
${ }^{1}$ The urgency for a different attitude towards non-standard varieties in typology is actually stressed very clearly e.g. in Kortmann (2004) and Murelli \& Kortmann (2011).
} 
The present article focusses on typological diversity within Romance, rather than on locating Romance typologically within the languages of the world, as is perhaps more usual in general works of this sort. To do so, however, it is useful to compare the Romance data against a general typological background. This will be provided by reference to WALS Online (Dryer \& Haspelmath $2013^{2}$ ), which can be considered a reference repository of typologically relevant phenomena, and is available online.

There isn't obviously enough space to claim any sort of coverage: just a few linguistic phenomena will be discussed. However, the four "case studies" under discussion span over the different levels of linguistic analysis, and hopefully each one is given sufficient space to hint also at the methodological questions that rise inevitably when one is confronted in practice with the issue of cross-linguistic comparability.

Section 2 is dedicated to major features in segmental phonology. In this domain Romance does not show anything spectacular at typological level, although the consideration of nonstandard varieties significantly enriches the picture. Section 3, dealing with plural marking, gives on the contrary a clear instance in which the apparent uniform landscape emerging from WALS data is simply due to the selection of just the major languages, which turn out to be very weak representatives of the actual state of affairs. Section 4 discusses head- vs. dependent-marking typology, which has been the object of important investigations with reference to the Romance languages, and is argued to raise issues of theory-dependent evaluations. Finally, Section 5 illustrates a favourite topic of syntactic diversity within Romance, the various strategies found for sentence negation and negative imperatives, comparing them again with their treatment in WALS.

\section{Segmental phonology}

The domain of segmental phonology is investigated in WALS by means of 13 maps (six more deal with suprasegmental features), mostly due to Ian Maddieson and based on the same, quite extended sample of around 567 languages. Two maps are due to other authors (Anderson 2013 and Hajek 2013) and are based on smaller samples (469 and 244 languages respectively). There are five Romance points in Maddieson's sample: Spanish, Catalan, French, Romansh (Sutselvan), Romanian. Only French and Spanish feature in the other two samples. From a romanicist's perspective, the complete absence of Italo-Romance (plus Sardinian) is surely remarkable, given the well-known diversity within Italo-Romance varieties. In this section, some features of Romance segmental phonology will be outlined on the background of the worldwide typological and areal perspective given by the WALS maps, trying to ascertain how much gets lost and how much can be still inferred from the small 5-languages subsample available there.

\subsection{Consonant inventories}

In WALS Map 1, Maddieson (2013a) identifies the average number of consonant phonemes in the world's languages to be around 22 (not counting distinctive length contrasts) and assigns

\footnotetext{
${ }^{2}$ In the following I will refer to Dryer \& Haspelmath (2013) as WALS for brevity, although I will constantly refer to the online version, as specified in the reference list.
} 
the "average value" to the band of $22 \pm 3$ phonemes. Basically, nearly all Romance varieties appear to be within this band, judging from Schmid (2016), the different descriptive chapters of Ledgeway \& Maiden (2016), and other sources especially for the Italo-Romance area (for brevity, we mention just Maiden \& Parry 1997 and references therein). The numbers for the main standard languages as given by Schmid (2016) are: French and Spanish 20, Portuguese 21, Catalan and Romanian 22, Italian 23, even if there is unavoidably some room for different values according to different analyses. For instance, not everyone would agree with Schmid's choice of counting $/ \mathrm{j} /$ and $/ \mathrm{w} /$ as distinctive segments in Italian and Romanian, as well in many other varieties; on the other side, Schmid does not include /c/ and / $/$ / for Romanian, which are present in Stan (2013a: 10).

A delicate issue in this sort of counts is how to treat phonemes originally foreign to the inherited stratum of the lexicon, but occurring in a good amount of well-established borrowings ${ }^{3}$. Maddieson's attitude is to reject phonemes found only in "recent" borrowings, and reference is especially made to the impact of colonial languages over a host of native languages throughout the world. As for Romance languages, descriptions are not really consistent: Romanian and Romansh /h/ are usually taken as part of the phonological system, $/ \mathrm{t} /$ in French much less so (e.g., Smith 2016: 298 mentions the option but does not take it: see, however, pairs like tchèque

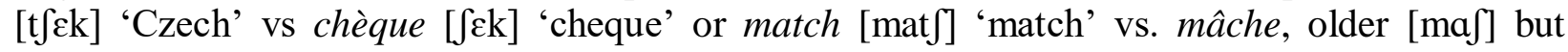
nowadays [maf] 'chew!'), and / $3 /$ in Italian practically never (despite a handful of usual words like beige or garage, normally pronounced [be3] and [ga'raz]). This has to do, intuitively, with the sheer quantity of commonly used borrowings containing such sounds, and/or with the absence of alternative, "natively oriented", options of phonological integration; but no clear-cut boundary can be traced, of course. The problem becomes more serious when dealing with nonstandard varieties, whose speakers, at the beginning of the 21th century, are nearly all bilingual with one of the main standard languages acting as a sociolinguistic "roof" (Dachsprache), and which, in any case, have plurisecular histories of intense contact with it. It would be perhaps safer, for sake of comparison, to try to limit inventories essentially to inherited strata throughout, but this is by no means obvious in many cases.

The fact that Romance consonant inventories mostly number around $22 \pm 3$ phonemes does not mean, of course, that the Romance languages share a common nucleus of about that size: it can be readily verified that the shared list cannot go above 14 and should probably be limited to 11 units $^{4}$, above which the phoneme inventories of the single languages are completed by rather disparate segments, although very few (if any) of them can be judged to be really unusual in a global perspective ${ }^{5}$.

\footnotetext{
${ }^{3}$ For a survey of methodological approaches dealing with the issue of phonological systems in borrowings, see for instance Calabrese \& Wetzels (2009).

${ }^{4}$ The probably undisputable 11 shared phonemes are /p t k b d g f s $1 \mathrm{~m} \mathrm{n} /$, plus other 3 at most: /r/ (if one considers $[\mathrm{R}] /[\mathrm{r}]$ and $[\mathrm{r}]$ as the same unit when a single rhotic is present in the system), $/ \mathrm{j} /$ (for some languages analyses diverge about treating it independently from /i/), /t $\mathrm{f} /$ (absent e.g. in French, standard Portuguese and Logudorese if borrowings are excluded). The total of 11 might be lowered if the allophonic alternations $[\mathrm{b}]-[\beta],[\mathrm{d}]-[\delta]$ and $[\mathrm{g}]-[\mathrm{\gamma}]$, as in Spanish and other Ibero-Romance varieties, are judged sufficient to exclude /b d g/ from the shared inventory, under the argument that the approximant realization is the more frequent one. This - somehow radical - choice is indeed made by Maddieson in WALS, as clearly reflected in his Maps 4 and 5 (Maddieson 2013b, 2013c).

5 Among the less frequent ones, in a Romance or worldwide perspective (or both), one could mention: / $/$ / (e.g., Spanish), /h/ (Romanian, Romansh), / $\theta$ / (Spanish, Nuorese, some Venetan dialects), / $/$ / (rather common in Romance but uncommon worldwide), /y/ (several northern Italo-Romance varieties, marginally Galician), /u/ (French), /c/ and /J/ (Friulian, Romansh, Corsican), /d/ (Sicilian and some other southern Italo-Romance dialects, Corsican, Sardinian).
} 
Coming back to the size of consonant inventories, the centering of Romance languages on the typologically average value of $22 \pm 3$ is further confirmed by the fact that it is relatively hard to find varieties located even at the two edges of the interval: e.g., those varieties of Friulian with both $/ \mathrm{c} /, / \mathrm{J} /$ and $/ \mathrm{J} /, / 3 /$ number 25 units (Benincà \& Vanelli 2016: 142) and Turinese only 19 (cf. the 18 units in Parry 1997: 239, to which /j/ should be added, but not /w/). However, outliers which display the two neighbouring values in Map 1 ("moderately large", 26-33 and "moderately small", 15-18) are also found, at least if the borderline choices are made in the favourable direction. Sursilvan and Surmiran would total 26 phonemes by coupling Schmid's (2016: 479) inclusion of /w/, /j/ with Anderson's (2016: 172) inclusion of / $/ \mathrm{y} /$; Vallader reaches 27 consonantal phonemes according to Schmid (2016: 479). On the other side, some varieties of Sardinian (Nuorese and Logudorese) have systems of 17 and even 16 consonantal phonemes (including $/ \mathrm{j} /$ ), if one does not take into account Italian borrowings (Mensching \& Remberger 2016: 275). It looks extremely improbable to find out a Romance variety assignable to the values "small" (14-) or "large" (33+), under the conventions adopted in Maddieson (2013a) (particularly, excluding geminates).

On the whole, it can be said that in this case the uniformity emerging from the small Romance subsample in WALS, essentially limited to the "big" standard varieties, does not do much damage, reflecting pretty well both the internal uniformity and the average typological location of Romance consonant inventories (in size). It may be noticed, finally, that this position of Romance systems does not coincide with the one of their parent language, Latin, which is placed at the border between the "small" and "moderately small" categories, with only 14 sure phonemes $\left(/ \mathrm{p} \mathrm{t} \mathrm{k} \mathrm{b} \mathrm{d} \mathrm{g} \mathrm{f} \mathrm{s} \mathrm{h} \mathrm{m} \mathrm{n} \mathrm{l} \mathrm{r} \mathrm{w/)} \mathrm{and} \mathrm{possibly} \mathrm{two} \mathrm{more}\left(/ \mathrm{j} /\right.\right.$ and $/ \mathrm{k}^{\mathrm{w}} /$, less probably also $/ \mathrm{g}^{\mathrm{w}} /$ ): cf. e.g. Weiss (2009: 58-63).

\subsection{Vowel inventories}

WALS Map 2 (Maddieson 2013d) is another case in which the subsample of just five Romance languages gives a resonable picture of the whole state of affairs, although in a different way. It is concerned with the size of vowel systems (only with respect to the three parameters of height, frontness and rounding: to make comparison easier, contrasts of length or nasalization, even when distinctive, do not modify the values, and diphthongs are not counted). This time there are just three values: small 2-4; average 5-6; large 7-14.

From a typological perspective, Romance languages surely cover a much larger spectrum in the vowels than in the consonants, and this is reflected even in the limited WALS sample: three languages fall under "large" and two under "average". If four values were used, splitting the "large" inventories into two, the WALS sample would still reflect the general picture, given that (standard) Catalan and Romanian would belong to the "moderately large" inventories (7 vowels each), while standard French (traditionally 12, but probably now 11, vowels, apart from nasals) would definitely be assigned to the "large" class also on a general typological level. French seems indeed to be rather extreme also worldwide, since the top value in Maddieson's (2013d) big sample of 567 languages is reached by just one language, German, with 14 vowel phonemes, and only two languages (including British English) total 13 units.

In fact, Romance languages align with whole Eurasia - with the exclusion of the Caucasus in displaying a mix of large and average vowel systems, but fully excluding the small inventories (under 5 vowels). Again, the Latin inventory of 5 vowels (given that length contrasts are excluded from WALS Map 2) is located at the lower edge of all Romance languages, but in this case the Latin minimum is also found in some modern varieties (Spanish, Logudorese). 
Innovations concern most often a fourth grade in height, but also up to three front rounded vowels (chiefly Gallo-Romance and northern Italo-Romance, but sparsely present elsewhere) and one or two non-low central segments (chiefly Romanian, but stressed /ə/ occurs also in Balearic Catalan and Piedmontese).

The periphericity of the Latin vowel system with respect to modern Romance is not as straightforward as it is for consonants, however. In fact, it is highly likely that the Latin spoken towards the end of the Classical period, while still keeping the length contrast, had already developed a significant difference in height - along with peripherality and tenseness - between long and short vowels (cf. Loporcaro 2011: 110-111), with $\breve{l}$ and $\bar{e}$ converging towards a common mid-high grade distinct from both high $\bar{l}$ and mid-low $\breve{e}$ (and the same for back vowels). In this perspective, even at times in which length opposition was preserved, Latin could already be treated as a 7-vowel system - indeed it should, if one adopts the choices Maddieson makes for English and German - and would have to be placed in the middle and not at the border of the modern Romance landscape.

The picture emerging from WALS would not change radically by zooming in on more Romance varieties; but, not unexpectedly, the gap between the 7-vowel system of Catalan and Romanian (and also of Italian, Portuguese, Campidanese, Friulian, Surmiran, most Occitan varieties) and the 11/12-vowel system of French would be easily and smoothly filled. For instance, starting from the "basic", symmetric 7-vowel system of the Catalan/Italian type, 8 vowels are found in Balearic Catalan (adding / / /); 9 in Turinese (further adding two front rounded segments, $/ y /$ and $/ \varnothing /$, but losing one grade in height in the back vowels); 10 in southern Piedmont varieties (which add a further distinctive low back / $/$ /). Still excluding length and/or nasality, Genoese also has 8 vowel phonemes, Engadinese Romansh and Badiot Ladin have 9, Travo (Piacenza) has 10 (Zörner 1989: 88-90), etc.

Finally, a complexity provided by non-standard languages concerns the balancing between the two series of peripheral vowels: front unrounded vs back rounded. All six major standard languages are symmetrical in this respect, but several other Romance varieties are not, displaying two back (typically /u o/) vs three front (/i e $\varepsilon /$ ) grades, and thus confirming the often observed tendency allowing for more distinctions in the anterior space (cf. Schmid 1999: 257). Asymmetrical systems include most Occitan varieties (Oliviéri \& Sauzet 2016: 322), some Catalan ones near Girona (GLC 2016: 39), and various northern Italo-Romance varieties like Turinese and Genoese.

\subsection{Typologically marked phonemes}

WALS is not particularly misleading also when it comes to detect the presence in Romance of segments which are relatively unusual at a typological level. There are several maps about this topic, focusing on: uvular consonants (Map 6, Maddieson 2013e); glottalized consonants (Map 7, Maddieson 2013f); lateral consonants other than /1/ (Map 8, Maddieson 2013g); velar nasal (Map 9. Anderson 2013); nasalized vowels (Map 10, Hayek 2013); front rounded vowels (Map 11, Maddieson 2013h); interdental fricatives, together with other sounds not relevant for Europe (Map 19, Maddieson 2013i). Despite the reduced amount of information for Romance, WALS detects uvular consonants, nasalized vowels and front rounded vowels (all three thanks to French), and interdental fricatives (thanks to Spanish). Clearly, there is no issue with glottalized consonants, as these are totally absent in Romance as well as in the whole Eurasia - again, with the robust exception of the Caucasus; and Map 8 does not capture the quite uncommon $/ K /$ (cf. 
Maddieson 1984: 77) simply because it does not look for it, concentrating on obstruent laterals. ${ }^{6}$ Thus, among the features examined, WALS fails to detect only one Romance contribution to a typologically marked segmental phoneme, namely the velar nasal (only weakly marked, in fact), which occurs in several northern Italo-Romance varieties, also between vowels (although not at word beginning), in Badiot Ladin and marginally in Galician and Romansh.

The discussion of front rounded vowels deserves some more detail, since a (tendential) implicational universal had been proposed in previous literature (Maddieson 1984: 14), which ranked high front rounded vowels as typologically less marked than non-high ones, or to put it briefly: $/ \varnothing /, / œ />/ y /$. A couple of exceptions were mentioned already in the original proposal by Maddieson (1984); Schmid (1999: 260) also discusses this topic with respect to a 44-varietysample within the Italo-Romance area, and finds two exceptions as well, although the tendency seems loosely confirmed to him. However, Maddieson himself is rather conclusive in dismissing the hypothesis when discussing WALS Map 11 (Maddieson 2013h). While front rounded vowels are definitely rare worldwide (about $6.6 \%$ of the 562-language sample, essentially concentrated in the Eurasian macro-area), the two values normally tend to occur together; and when only one of them occurs, there is clearly no statistical primacy of high vs mid. Within Italo-Romance, a further counterexample may be added to the ones in Schmid (1999): several Piedmontese varieties of Monferrato have lost /y/ via the cross-linguistically common change [y] > [i] (e.g. It. ['luna], Turinese ['lyna], Monferrato ['lina] 'moon'), but retain a well established $/ \varnothing /$.

Summing up, concerning segmental phonology the data provided by WALS do not offer an exceedingly simplified picture of the Romance state of affairs, although they rely on just five varieties (at most) and fully ignore Italo-Romance. Regarding the overall size of Romance phoneme inventories, the limited WALS sample does not distort the situation too much, either because the whole Romance domain is essentially uniform (the size of the consonant inventory), or because diversity is indeed there (the vowels), but is also reflected in the sample chosen. Some instances of phonemes present in Romance but uncommon worldwide, and especially in the Eurasian macro-area, are also partially captured by WALS data, given that they happen to occur in French or Spanish; among those which escape notice, one could mention the velar nasal $/ \mathrm{y} /$. Another significantly marked class of phonemes - not investigated at all in WALS - which would not have surfaced in the 5-language sample is given by retroflex consonants, occurring distinctively in Sardinian, southern Corsican, Sicilian, and some varieties of Puglia and Calabria.

In $\S 3$ it will be seen that WALS may be more misleading in an area of morphology, where it suggests for Romance a picture of uniformity which is very far from real data.

\section{Plural marking}

The issue of plural marking is dealt with in WALS chiefly in two maps: 33 "Coding of nominal plurality" (Dryer 2013a), and 34 "Occurrence of Nominal Plurality" (Haspelmath 2013a). Haspelmath's sample of 291 languages includes the usual five major Romance languages (Spanish, Portuguese, French, Italian, Romanian). Given the huge dimension of Dryer's sample (1066 languages), one could perhaps expect a wider coverage, but his Romance subsample adds

\footnotetext{
${ }^{6}$ A much rarer segment, namely an interdental lateral approximant, is identified by Loporcaro \& Mancuso (1998), who propose the symbol $\left[\delta^{1}\right]$, in some Calabrian varieties, originating as an intermediate stage of the more widespread change [1] > [ð] /_V. Since [1:] remains unchanged, [ð] and [1] are allophones, but the default realization is clearly [ $\left.\chi^{l}\right]$, so that, adopting Maddieson's criteria mentioned in Footnote 4, one could identify $/ \mathrm{J}^{1 /}$ as the lateral phoneme for these varieties (M. Loporcaro, p.c.).
} 
only Sardinian to the abovementioned five major languages, so it is proportionally less extended than Maddieson's.

Dryer investigates both the morphological and the syntactic expression of plural, and, within morphological expressions, which procedure is used. The syntactic and quasi-syntactic strategies are identified by two values: "plural word" and "plural clitic"; the morphological strategies are distinguished according to five procedures (prefix, suffix, tone, stem change and full reduplication: partial reduplication goes with either suffixing or prefixing). A further value "no plural" does not refer to the absence of the category altogether, but to the absence of any marking on the noun (although Dryer mentions as a possible alternative only the marking on verbs, and it is not clear how he treats instances of marking in the NP, but not on its head). As is customary in typology, all values must be understood in a prototypical sense: in the presence of more than one strategy, the value is assigned to the dominant one, if there is one. In cases when at least two strategies appear to be balanced and productive, there is a further value at disposal, namely "mixed type": this is employed for instance for Arabic varieties, whose lexicon is taken to be more or less equally divided between the stem-changing and suffixal strategies. An exception occurs with the "no plural" value, which is not treated on a par with the other procedures, but rather like a last resort: if a non-zero strategy is present in the language, be it in a (little) minority of nouns, the corresponding value is assigned. Major issues of delimitation concern precisely the threshold licensing the mixed type (German Umlaut plurals are evidently considered to be below it, despite their not so marginal diffusion in the core lexicon, and some residual productivity), and the (fuzzy) boundaries between plural word and plural clitic.

Despite these probably unavoidable difficulties, WALS data point quite clearly towards a dominance of the morphological strategies over the syntactic ones (717 vs. 251 languages). Within morphology, suffixation appears largely dominant, with a ratio of about $4: 1$ vs prefixation, and the remaining three procedures emerge as extremely marginal worldwide (the occurrences of each of them are counted in unities, although reduplication might have enjoyed some more visibility if the instances of partial reduplication were included).

In Dryer's (2013a) WALS Map 33, Romance data look absolutely ordinary and uniform, since all six languages are assigned the cross-linguistically dominant option, i.e. "suffixal plural". Such an assignment, however, is very questionable for French, even within the limits of a typological approach. Obviously, despite the orthography, French nouns are nearly all invariable (the very few exceptions being some masculine nouns ending in -al, like cheval

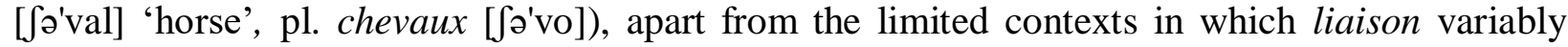
applies - as when a plural noun is followed by a modifier beginning with a vowel (the type jeux

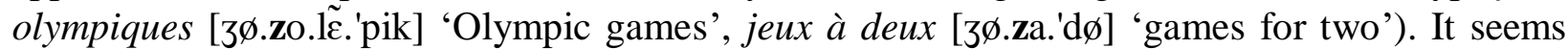
unconvincing to consider the scattered liaison contexts involving plural nouns (for details, see e.g. Sampson 2016: 676-677) as sufficient to assign the value "suffixal plural" to French". On the other hand, the cheval type, marginal as it is, would at most imply a description in terms of stem-changing, rather than suffixing, morphology. Of course, plural is very consistently signaled in French - as in every other Romance language - at the DP/NP level, given that the number opposition is very solid among determiners: [la='pom] 'the apple' vs [le='pom] 'the apples', or, with additional liaison, [l=a'mi] 'the friend' vs [lez=a'mi] 'the friends'. This is a fact of relevant

\footnotetext{
${ }^{7}$ A further problem with liaison is that whenever it occurs, it is prosodically much more narrowly linked with the following word (interruption in the verbal flow, e.g. an hesitation pause, is normally possible only before the [z]), so that the [z] mark, if relevant, should probably be labelled as a "plural clitic", which takes as a host the word following the N, irrespective of its category, as mentioned in Sampson (2016: 676) and suggested also in an unanswered remark found on WALS online.
} 
typological significance in itself (see $\S 4$ ), which, however, does not seem to play any role in the criteria to build Map 33.

Map 33 also disregards the distinction between a privative number opposition, best shown in the Spanish plural mark -s/-es contrasting with no marking in the singular (e.g., casa, pl. casa-s 'house(s)', libro, pl. libro-s 'book(s)', león, pl. leon-es 'lion(s)'), and the equipollent opposition which - apart from few invariables - is general in Italian (cas-a, pl. cas-e, libr-o, pl. libr-i, leon-e pl. leon-i). However, this can be ascribed to the necessary simplifications characterizing any typological investigation.

More importantly, the image of uniformity in Romance pluralization strategies fully disappears if one zooms in onto nonstandard varieties. Italy provides the most complex - and complete - picture in this respect.

First, in most northern Italo-Romance varieties (Ligurian and central Venetan excluded), given the loss of all final vowels except $-a$, nearly all masculine nouns are invariable, and there are no phenomena parallel to French liaison to trouble the picture. This involves presumably more than half of the lexicon (most feminines contrast singular with plural, due to the conservation of final - $a$ and the evolution - if one follows Maiden 1996 - of plural -AS into an -[e] which, arising later, was often not deleted), but would not change the assignment value in Map 33, because, as said above, Dryer (2013a) does not treat "no plural" as a type on its own, so that a 50\% mixture between suffixed and invariable nouns is not a mixed type for him. However, there are varieties in which metaphonic plurals (induced by a plural suffix -[i] which was subsequently lost) are so pervasive among masculines that they have to be considered a major type $^{8}$. This holds especially true for Romagnol varieties, as the one from Lugo quoted in Savoia \& Maiden (1997: 21; to be true to the original, some of the instances given in 1 are of adjectives, but nouns behave identically). Combining the pattern in 1, holding for most masculines, with a suffixal one for feminines (which are rarely subject to metaphony) would give a "mixed type" value.

(Romagnol)
a. [spos] 'husband' $\rightarrow$ pl. [spus]
b. [mo'rt] 'dead: $M$ ' $\rightarrow$ pl. [murt]
c. [a'mea r] 'bitter: $\mathrm{M}^{\prime} \rightarrow$ pl. [a'mer]
d. [mes] 'month' $\rightarrow$ pl. [mis]
e. [bel] 'beautiful:M' $\rightarrow$ pl. $\left[b^{a}{ }^{a} 1\right]$

In Ladin and Friulian, another kind of mechanism could, in principle, generate a mixed type. The dominant strategy in all varieties is $-s$ suffixing, coming from the Latin plural accusative, but in most of them there is a class of masculine nouns ending in a coronal (sometimes also a velar), whose plural was formed by adding the $-i$ ending coming from Latin plural nominative. However, these plurals further evolved, by coalescence of -[i] with the preceding consonants, to give palatal consonants as output. Badiot is among the Ladin varieties in which this formation is most widespread. Examples (taken from Haiman \& Benincà 1992: 117) are [fyk] - [fyt ] 'fire(s)', [an] - [an] 'year(s)', [mys] - [myf] 'mouse/mice'. In Friulian (Benincà \& Vanelli 2016:

\footnotetext{
${ }^{8}$ Stem-change strategies originated by [i]-metaphony and subsequent loss of [i] must have been much more widespread in northern Italy varieties in the past (Savoia \& Maiden 1997: 16), but in many of them they have been completely levelled, or they survive in few residual items.
} 
144) these plurals are only found in a closed, residual class (e.g. [dint] 'tooth', pl. [dinc]), apart from some productivity for words ending in [1] or -[st] ([ca'val] 'horse', pl. [ca'vaj]).

Synchronically, the type [dint]/[dinc] is not suffixal any more, but must be described in terms of stem change. In general, however, its quantitative relevance does not seem enough to license a "mixed type" assignment for such varieties according to Dryer's criteria.

In southern Italy it is also possible to find varieties in which stem change is the sole strategy available, apart from invariability. This occurs because in these varieties all final unstressed vowels, [a] included, neutralized to [ə], and later often to zero. So feminines do not pattern differently from masculines, and are all invariable apart from metaphony effects. Metaphony, however, is normally triggered by both [i] and [u] in southern Italy, which implies that it has morphological relevance only for the inflectional class roughly corresponding to Latin third declension nouns: feminines coming from Latin first declension are untouched by metaphony, and masculines coming from Latin second declension are subject to metaphony both in the singular (triggered by [u]) and in the plural (by [i]). ${ }^{9}$ Therefore, differently from Romagnol, only a minority of nouns display stem-changing pluralization: but since there is no other competing strategy apart from invariability, these varieties would necessarily get a "stem change" value (not a "mixed type" like Romagnol) in Dryer's map.

Finally, the most "exotic" instance in Romance plural marking is found in western Lombard and Emilian varieties. They couple the invariable masculines with a subtractive process (or, in more general terms, an anti-iconic one ${ }^{10}$ ) for the -[a] feminines: Milanese [la 'skarpa], pl. [i 'skarp] 'the shoe(s)'. Diachronically, we have to suppose that the $*_{-} e$ coming from Latin -AS was also deleted, at a later phase. For these languages, if we disregard the little minority of masculines showing distinctive plurals - essentially, the ones ending in - $l$ like [ka'val] pl. [ka'vaj] 'horse(s)', as in practically all of northern Italy -, we have to introduce a value even rarer than stem change, tone or full reduplication: namely, subtraction, which is so rare that it does not surface at all among the over 1,000 languages in Map 33. In some Romagnol varieties, the same subtractive strategy for feminines is present, but, coupling with the metaphonic masculine plurals seen in 1, it gives a further type of mixed combination (stem change + subtraction).

Outside Italy, some interesting cases are also present, of course. Those Andalusian varieties of Spanish could be mentioned, in which final -[s] has disappeared altogether (cf. Penny 2000: $122-125,148-150)$, so that the "no plural" value is unavoidable. In Romanian, the suffixal strategy very often coexists with stem change, but syntagmatically, as a double-marking on the same noun (all the following examples from Stan 2013b: 607-609). Stem change may involve

\footnotetext{
${ }^{9}$ Needless to say, this is a very simplified picture. There are southern varieties (in eastern Abruzzo, Savoia \& Maiden 1997: 20) in which metaphony is triggered by -[i] only, as in the North, and therefore masculines corresponding to the Latin second declension also display stem alternation; and the inverted pattern of stem change, in which the singular only is subject to metaphony, is found in the distinct inflectional class originating (with new entries from other classes) from second declension neuters, whose plural ended in $-a$ : e.g., Ischia ['wossə] (< OSSU) 'bone', ['ossə] (< OSSA) 'bones' (Savoia \& Maiden 1997: 19). Moreover, analogical extensions often add further complexity.

${ }^{10}$ Under a strict definition of 'subtraction' (as in Dressler 2000: 583), the processes involving zero marking for semantically marked/additive notions (as is here the case for the plural vs. the singular) may not be termed subtractive, but they surely remain anti-iconic: thus a general and productive procedure contrasting a marked singular ['skarp-a] with an unmarked plural [skarp] would anyway require a different label in Dryer's (2013a) typology. In the following, however, we prefer to keep the term 'subtractive', for simplicity but especially because the segmentation of the final [-a] in [la 'skarp-a] looks rather circular, given that the relatively few Milanese masculine nouns in -[a] (like [el 'para] 'the.M.SG pair') do not lose the -[a] in the plural and remain invariable ([i 'para] 'the.PL pairs'; Nicoli 1983: 96).
} 
the final consonant (e.g. ste-a 'star', pl. stel-e, brad 'fir', pl. braz-i [braz']); the internal vowel (fat-ă 'girl', pl. fet-e, cuvânt [ku'vint] 'word', pl. cuvint-e); or both (poart-ă 'door', pl. port-i [ports ${ }^{\mathrm{j}}$ ). There are also instances of plural marking exclusively by stem change (like rac [rak] 'crayfish', pl. raci [ratf], urs 'bear', pl. ursi [urf]). Moreover, there are very many borderline cases, in which plurals are exclusively marked by a final "segment" of palatalization [j] (orthographically $i$ ) whose phonological status is problematic (Maiden 2016: 93): lup 'wolf', pl. lupi [lup'], englez 'Englishman', pl. englezi [en'glez']; however, this ['] resolves into a properly suffixal -[i] when followed by a clitic article: ['lupilor] 'of the wolves'. Double exponence is another type not taken into account explicitly in Dryer's survey; perhaps "stem change", being by far the more marked strategy of the two, could be extended to it, although Dryer's choice has privileged suffixation for Romanian.

Briefly, four values out of seven (plus an entirely new one, subtraction) would feature in a true representation of the Romance state of affairs concerning morphological plural marking strategies, and, moreover, "clitic plural" could be an option for French: a picture radically different from the single-coloured landscape retrievable from Dryer's (2013a) WALS Map 33 (not just for the Romance-speaking area, but for all of Europe, Basque excluded).

The obligatoriness issue, treated in Haspelmath's (2013a) Map 34, is probably less relevant, since in no Romance language plural marking appears to depend on the animacy/humanness and definiteness factors on which the typological investigation of Map 34 is focused. However, as already seen in this section, plural marking on nouns is certainly not obligatory in all Romance varieties (particularly French, when it occurs only in a minority of contexts for nearly all nouns, or Andalusian Spanish), differently from what appears in the map. The obligatoriness of plural marking, on the contrary, would substantially hold throughout Romance if referred to the whole NP (or the DP in most generative models), which presumably would be a more significant typological parameter to investigate. Indeed, it is the DP/NP which is semantically and referentially involved in the notion of plurality, not the noun alone. This point has to do with the topic of $\S 4$, at the border between morphology and syntax: how Romance languages fare with head-marking vs. dependent-marking typology.

\section{Head-marking vs dependent-marking}

The typology of head-marking vs. dependent-marking (first set up by Nichols 1986) is also reflected in some WALS maps (especially Maps 23, 24, 25: Nichols \& Bickel 2013a, 2013b, 2013c).

On Map 24 ("Locus of marking in possessive noun phrases"), the two Romance languages French and Spanish - are represented uniformly under the option "dependent-marking". Indeed, possession is overwhelmingly dependent-marked in Romance languages, although mostly conveyed by a preposition, since the preposition is a clitic linked syntactically and prosodically to the following noun, the possessor. However, there are sure, if limited, instances of headmarking in several dialects of Southern Italy, in which kinship terms, and sometimes a few other nouns very high on the definiteness scale, may display a first and second person singular possessive marker suffixed to the possessor: e.g., Neapolitan ['mammotə] 'your mother' (cf. Ledgeway 2009: 268-270). This raises the more general question of how to deal with possessive adjectives in general, since in several languages they may have clitic status (Spanish sus amigos, French ses amis 'his/her friends') and therefore they could also be considered as marking the possession relation on the head noun. This is surely the stance taken e.g. by Ledgeway (2012: 
289), when he describes colloquial French son mobile à lui 'his mobile', lit. 'his mobile to him', as an instance of double-marking strategy.

The direct object marking, discussed in Map 23, raises more complex issues, as will be seen below. And considering the typology on the whole, surely a significant discrepancy can be identified between Latin and its Romance descendants (and partially within Romance), as stressed by Ledgeway (2012: 284-311).

As stated for instance by Vincent (1997: 164), Latin was near to the prototypical instance of a dependent-marking language. The prepositional phrases displayed case marking on their dependent nouns; the possessive relationship was equally marked on the possessor exclusively, by the genitive case; verbal arguments other than the subject were again marked chiefly by cases, or sometimes through PP, but never on the verb.

The most significant partial exception was given by the subject, which displayed doublemarking (on the "dependent" noun via nominative case and on the verb via agreement). There is little surprise here, since subject agreement on the verb is by large the most frequent headmarking feature cross-linguistically (Nichols 1986, Ledgeway 2012: 286). Moreover, subject agreement in the verb is questionable as an instance of head-marking per se, since such a treatment implies that the subject is considered a "dependent" of the verb on a par with the other arguments, which is part of Nichols' original approach, but is certainly not shared by many other theoretical perspectives, particularly within the generative framework ${ }^{11}$.

Without reaching a full inversion of the inherited state of affairs, Romance languages are now much removed from the prototype of a dependent-marking language. As said at the beginning of this section, the possessive relation is still overwhelmingly dependent-marked; on the contrary, due to the nearly complete demise of cases, Romance prepositional phrases are essentially a matter of neutral (zero) marking: both the head (Prep) and the dependent $(\mathrm{N})$ are unmarked with respect to their relation. The main instances of residual dependent-marking in PPs are given by the distinctive non-subject marking of some free personal pronouns. This is widespread, but not general, in the first and second singular (e.g., in Spanish, subject yo/tú vs. PP para mí/tí, in Standard Italian io/tu vs. per me/te); some varieties keep the contrast in the first person only (Tuscan io vs. per me, but te everywhere; Catalan jo vs. per a mi, but $t u$ everywhere), while French (moi/toi), modern Occitan (mostly ieu/tu, Oliviéri \& Sauzet 2016: 331) and northern Italo-Romance (mostly $\mathrm{mi} / \mathrm{ti}$ ) display full neutralization. Other varieties, on the contrary, have a more extended set of options for non-subject marking of first and second person singular pronouns, reaching a Romance maximum of four distinct forms, among which a maximum of three can be governed by prepositions (details differ: see Loporcaro 2009, Cappellaro 2016).

Romanian keeps a two-case opposition in nouns as well, which marginally translates into dependent-marking in PPs, since some weakly grammaticalized prepositions govern the genitivedative case instead of the nominative-accusative (Nedelcu 2013: 458-459).

The most complex issue is given by marking patterns in the VP. If - questionably as said above - subject is included into the picture, the loss of a distinct nominative form and the retention of verb agreement (although with several syncretisms in some languages, most of all in French), plus the rise of subject clitics in a central area of the Romance domain, implies a transition from double-marking to head-marking. On the other hand, oblique arguments basically

\footnotetext{
${ }^{11}$ However, generative approaches like Ledgeway (2012) do take subject agreement on verbs (both morphological and via subject clitics) as an instance of head-marking, by referring to the fact that such markers "are now affixed to the auxiliary or lexical verb under I(nfl), where they spell-out and/or match the features of the subject in its canonical preverbal subject position in the Spec of IP" ((Ledgeway 2012: 292-293). Still, the verb they mark cannot be considered the subject's head, as Nichols' original concept of head-marking seems to imply.
} 
retain dependent-marking (now via prepositions), apart from few instances of neutral marking for the arguments of verbs like 'last' or 'weigh'.

The issue is less straightforward for both direct and indirect object. In the following we will refer to these two arguments as $\mathrm{P}$ and $\mathrm{R}$ respectively, as is common usage in typology, although there is no real unanimity in the interpretation of these labels, as extensively discussed in Haspelmath (2011).

Concerning $\mathrm{P}$, on the one hand dependent-marking has retracted by the loss of accusative case, but not as extensively as in prepositional phrases. In fact, beside the residual retention of pronominal accusative marking for first and second singular personal pronouns, with a distribution more or less parallel to the case of PPs, a very significant innovative instance of dependent-marking of $\mathrm{P}$ has emerged in many Romance varieties. This is the well-known "differential object marking" - hereafter DOM - by means of a preposition (mostly, but not exclusively, the one also employed for $\mathrm{R}$, issued from Latin AD; different options occur in Romanian pe 'on', and in various Italo-Romance dialects). As the name tells, such object marking is restricted to a subset of nouns, not identical in different languages but universally linkable to some upper segment of the double hierarchy of animacy/definiteness, with topicality also playing a role: all three features can be seen as independent facets of a single macroparameter of high level of individuation. Conditions differ from language to language, and cannot even be summarized here (see e.g. Bossong 1998; Aissen 2003; Fiorentino 2003; Iemmolo 2010).

On the other hand, however, besides this renovation of dependent-marking, Romance languages also display a relevant strategy of head-marking for $\mathrm{P}$, not found at all in Latin. This is realized via cross-referencing on the verb by means of clitic pronouns, themselves a major innovation in Romance. All Romance languages have object clitics, but the extent to which they can be considered instances of head-marking proper differs, and may be crucially related to their status in terms of grammaticalization. Let's consider, as an illustration, the Italian sentences in 2:
a. conosco
questa città
know.IND.PRS.1SG this.F.SG city
'I know this city'.
b. la $=\quad$ conosco, questa città
ACC.F.3SG= know.IND.PRS.1SG this.F.SG city
'I know it, this city'.

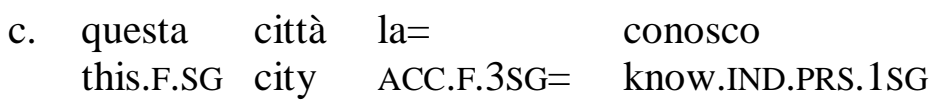
'This city, I know it'.

$2 \mathrm{a}$ is an instance of neutral marking: $\mathrm{P}$ is not marked at all, neither on the dependent (the NP questa città) nor on the head (the verb conosco). In 2b,c, however, the object clitic la encodes the $\mathrm{P}$ role of the NP, together with its number and gender features (feminine singular). No doubt, $2 \mathrm{~b}, \mathrm{c}$ are instances of head-marking of $\mathrm{P}$ in Italian.

Constructions like $2 \mathrm{~b}, \mathrm{c}$, traditionally named "right and left dislocations" respectively, are widespread in all Romance languages, and they are attested in their entire history. The moot 
point is, however, that in Italian - as in most Romance languages - $2 \mathrm{a}$ and $2 \mathrm{~b}, \mathrm{c}$ are not freely interchangeable in most contexts, since they are not pragmatically equivalent: simplifying considerably, dislocation constructions tend to express topicalization of the NP involved. In Italian, there are no NPs for which dislocation constructions - and therefore head-marking of P are obligatory. Thus, assigning an unequivocal P-marking value to Italian in a typological map like WALS Map 23 - would not be straightforward at all. However, it could be argued that in Italian the default construction, i.e. both the most frequent and less marked pragmatically, is still 2a: therefore, if one does not want to have recourse to a "mixed type" value, a no-marking value would be preferable (leaving aside, of course, the residual accusative marking of two personal pronouns). A similar state of affairs holds for French, one of the just two Romance languages considered in Map 23, in which it indeed gets the 'no-marking' value.

In the same map, however, Spanish is considered a double-marking language reflecting cases such as in 3a, which is definitely more controversial. Spanish certainly has a lot of dependent Pmarking in nouns, being a typical DOM language: he visto un coche 'I've seen a car' but he visto a Juan 'I've seen John'. However, it is by no means sure that dependent-marked P's are the default instance, because - again with much simplification - they basically need to be animate and definite, or indefinite specific at most. Now, $\mathrm{P}$ arguments are not typically animate neither typically definite, so that probably sentences with unmarked Ps are the most frequent type. Nichols \& Bickel (2013a) are aware of this, but they simply state that, for languages with differential object marking on nouns, they have selected for value-assignment the overtly marked strategy, without further comment ${ }^{12}$. Moreover, labelling Spanish as a double P-marking language also implies that its instances of head-marking, on the lines of $2 b, c$, are considered the basic construction, which is not obvious either. Spanish indeed has some instances of obligatory head-marking, differently from French and Italian. In cases like:

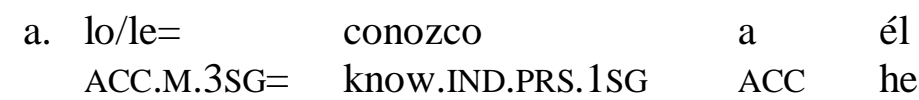

'I know him'

b. $10=$ conozco todo

ACC.M.3SG= know.IND.PRS.1SG

all.M.SG

'I know everything'

where $\mathrm{P}$ is a personal pronoun or the indefinite 'everything', there is no option of dropping the clitic, and consequently these constructions do not carry any marked pragmatic value. But this is not (yet?) the case for most constructions involving NP's: the Spanish translation of 2a, conozco esta ciudad, is perfectly grammatical, as is conozco a Juan. Therefore, there is little consistency in treating French and (at least standard) Spanish in opposite ways with respect to head-marking on $\mathrm{P}$, although Spanish shows great diatopic variation in this respect, and in some American varieties the full grammaticalization of clitic constructions equivalent to the Italian type $2 \mathrm{~b}, \mathrm{c}$ seems to be very advanced.

Romanian, another language with widespread prepositional object-marking, offers a further complexity, in that the dependent-marking and head-marking strongly correlate with each other (examples from Pană Dindelegan 2013: 136-138). Any instance of P-marking with pe (except

\footnotetext{
${ }^{12}$ By the way, the value "dependent-marking" assigned to English in Map 23 is completely mysterious (pronouns are out of consideration in this map) and is surely a mistake.
} 
the collocations with [+animate] interrogative and indefinite pronouns pe cine 'who' and pe cineva 'someone') almost requires the simultaneous presence of the object clitic, without pragmatic value, as in 4:
a. $\hat{\mathrm{I}}=$ ACC.M. $3 \mathrm{SG}=$ văd
see:IND.PRS.1SG
pe Ion
ACC Ion
'I see Ion'
b. ??văd pe $\operatorname{Ion}^{13}$.

The opposite implication does not hold, however, since clitic head-marking is also obligatory for preverbal definite non-animate nouns, where pe is excluded $(5 a, b)$. In this case, the clitic construction is pragmatically informative, because it is impossible with a postverbal object (5c), when it is not intonationally separated in a topicalizing right dislocation construction:
a. bibliografia
a citit $=0$
de
mult
bibliography.DEF.ACC has
read.PTCP.PST=ACC.F.3SG of/from
much
'(S)he read the bibliography long time ago'
b. *pe bibliografie a citit-o de mult
c. *a citit-o bibliografia

Therefore, if one accepts the choice of privileging the overtly marked Ps in case of DOM languages, the double-marking value would be more adequate for Romanian than it is for Spanish.

The same issue of head-marking via clitics arises with the marking of $\mathrm{R}$. In this case, dependent-marking is not in question, and is realized chiefly via the preposition cognate with Latin $\mathrm{AD}$ (in Romanian, however, there is a different preposition la, and $\mathrm{R}$ may also be marked with the dative case). But many varieties have evolved from exclusive dependent-marking towards double-marking, with $\mathrm{R}$ also marked by a dative clitic on the verb, via constructions similar to 2b,c. Obligatoriness issues arise also here, but the trend of grammaticalization appears to be more advanced than for P. R head-marking on the verb, with all nouns, is almost obligatory in many varieties of Spanish (Company 2001: 28) and in many (especially northern) ItaloRomance varieties, although not in Italian. A Venetan example (Poletto 1997: 141) is the following:

$$
\begin{aligned}
& \text { [ge }=\quad \text { lo }=\quad \text { dago } \quad \text { a } \quad \text { 'toni }] \\
& \text { DAT. } 3 \mathrm{SG}=\text { ACC.M. } 3 \mathrm{SG}=\text { give.IND.PRS. } 1 \mathrm{SG} \text { to Toni }
\end{aligned}
$$

'I give it to Toni'.

For these varieties, double-marking of $\mathrm{R}$ would undoubtedly be the right descriptive choice.

\footnotetext{
${ }^{13}$ The marginal acceptability given in $4 \mathrm{~b}$ reflects the commentary by Pană Dindelegan (2013: 138) that "the rule of the doubling of a post-verbal PE-nominal phrase has become obligatory in recent decades; the present-day use still shows some fluctuation".
} 
The data discussed in this section have shown that Romance languages all display a trend although in different grades - of expanding head-marking constructions, which were essentially absent in Latin. This perspective may be much strengthened, as Ledgeway (2012) does, if one subsumes under head-marking other kinds of phenomena, which, however, are highly sensitive to theoretical options concerning the very notion of head (as Ledgeway himself is aware of, cf. Ledgeway 2012: $201 \mathrm{fn}$. 29). A clear case is given by the tendency of several Romance languages, mentioned in $\S 3$, to maintain number marking within the nominal complex (be it called NP or DP) only in determiners and quantifiers, leaving the noun uninflected for number. The data are unproblematic in this case, but their interpretation is not.

Number marking in a Latin phrase like ille liber / illi libri 'that book/ those books', or in the Old English near-equivalents sēo $b \bar{o} c$ 'that.F book(F).SG' / $p \bar{a} b \bar{e} c$ 'those book(F).PL', was unquestionably a case of double-marking, irrespective of theoretical assumptions about phrase structure, since both the determiner and the noun carried number information. But the patterns of English the book/books and French [lə/le 'livs], diverging in opposite directions from their ancestors, can be interpreted both ways. In the DP approach now dominant within generative framework, the French type indeed describes a change towards head-marking, because the head is the determiner; and reciprocally the Modern English type, though limited to articles and possessives, would qualify as an increase in dependent-marking strategies. But exactly the opposite conclusion would be drawn if one takes a more semantically oriented notion of head, with the phrases les livres/the books headed by the noun (as in previous generative versions, and also in the framework on which the original Nichols 1986's proposal is based).

In the same vein, Ledgeway (2012: 289-299) aligns under the trend of head-marking expansion various instances of the tendency towards expressing grammatical content via newly emerging functional head categories (in particular auxiliaries and complementizers). For instance, in many southern Italo-Romance varieties and in Romanian the distinction between indicative and subjunctive moods has been nearly or even fully neutralized in the verb, but is now stably encoded via the choice between two different complementizers (e.g. Salentino $c a$ IND vs. $c u$ SUBJ, Romanian $c \breve{a}$ IND vs $s \breve{a}$ SUBJ), which in the generative framework are treated as superordinate heads to the whole verb complex.

There is no space to discuss these proposals further: they seem anyway to push the notion of head-marking vs. dependent-marking somehow beyond its original content. It may just be mentioned that even in the domain of prepositional phrases, which in Romance seem to display neutral marking, Ledgeway (2012: 291) suggests to identify traces of head-marking in cases where the contrast between position and motion has come to be encoded via contrasting lexical choices of different prepositions. Compare the three different strategies of Latin, Italian, and Spanish in 7a-c respectively (example mine, relevant markers in bold):

(7) a. (Latin)

$\begin{array}{llll}\text { vivit in urb-e } & \text { it } & \text { in urb-em } & \text { dependent-marking } \\ \text { lives in city-ABL.SG } & \text { goes in city-ACC.SG } & \end{array}$

b. (Italian)

$\begin{array}{lll}\text { vive in città } & \text { va in città } \\ \text { lives in city } & \text { goes in city }\end{array}$

neutral marking

c. (Spanish)

vive en la ciudad va a la ciudad head-marking?




\title{
lives in DEF.F.SG city goes to DEF.F.SG city
}

\author{
'(s)he lives in the city' '(s)he goes (in)to the city'.
}

The pattern in 7 , however, does not look very systematic and is hardly interpretable as a grammatical shift, given that it involves rather idiosyncratic lexical choices in the different languages.

\section{Sentence negation and prohibitives}

Sentence negation is another favourite topic in typology, and one in which Romance languages display remarkable diversity. The WALS online gives a significant space to sentence negation, chiefly in Maps 112, 143, 144 (Dryer 2013b, 2013c, 2013d), but also, concentrating on different aspects of the issue, in Maps 113, 114 (Miestamo 2013a, 2013b) and 71 (van der Auwera \& Lejeune 2013), plus the interaction with negative indefinites in Map 115, which will not be discussed here (Haspelmath 2013b).

Dryer's huge sample of over 1,300 languages provides a fairly extensive coverage of Romance languages: the 8 points included (Portuguese, Spanish, Catalan, French, Italian, Sardinian, Sursilvan, Romanian) essentially leave out only the internal diversity within ItaloRomance, which, however, is not a minor loss, as will be seen below.

Map 112 deals with the formal side of the negation strategies, isolating three main types: two syntactic (negative "particles" and negative verbs), and one morphological (negative affixes). Romance is fully uniform in this respect, always having recourse to a "particle" to express negation, which also appears to be the unmarked option worldwide, covering about half of the languages considered. Even if it is rather unclear what exactly a "particle" is, and surely there are fuzzy boundaries with both other options, one can be rather confident that, as far as Romance is concerned, its negators are neither verbs nor affixes.

Things become much more complicated, and surely not uniform, when the position of the negator comes into consideration. Dryer dedicates two main maps to this topic (143 and 144), with many submaps, but for reasons of space reference will be made mainly to Map 143A ("Order of negative morpheme and verb"). A first important methodological question concerns the formal diversity of negators. Dryer works on a strictly functionalist approach: therefore, when dealing with ordering issues, he does not see any problem in grouping under the same label (for instance, preverbal negation) items which belong to very different parts of speech. But, aiming at correlating word order patterns as Dryer is chiefly interested in, it is unclear how meaningful it is taking together, say, the negators of basically verbal nature with those which are essentially adverbs, or at least developed from them or even from nominal constituents. The syntactic position of these elements may in fact be more strictly related to the very diverse syntactic properties of the part of speech they originally - and sometimes also synchronically belong to, rather than to their semantic content.

At any rate, given that all Romance languages have particle-like syntactic negation, the issue above is not crucial here. One could think of a basic twofold choice: preverbal (NegV: the Latin starting point, unchanged e.g in Spanish or Romanian) vs. postverbal (VNeg); but this binary contrast reveals itself far too simplistic even for a typological survey. There are at least three main complications to be considered: (i) what about the option of two particles at either side of the verb? (ii) what about different syntactic positions for the same item (or different items) in a 
given language, depending on syntactic, or perhaps semantic and pragmatic factors? (iii) and finally, which "verb" has to be taken as the reference point, when auxiliaries are present?

Dryer's Map 143A and the following ones explicitly take point (i) into account: double negation (which is definitely a salient topic in Romance) has values on its own, further distinguishing between obligatory and optional double-marking. The map's commentary makes it clear that under "optional" both instances of grammatically and "extragrammatically" conditioned alternatives are included (it is unclear if pragmatically conditioned alternatives are subsumed under the former or the latter). This is a little misleading, because a grammatically conditioned alternative is not really a matter of optionality; but it explains why two Romance points with different systems are both assigned the value of "optional double negation" in Map 143A, namely French and Catalan.

The optionality of the double negation pattern for French is essentially extragrammatical in nature. As is well known, simplifying a bit (because there are few contexts in which even the simple preverbal $n e$ is still possible at a very formal level, e.g. before pouvoir 'be able to') the double negation ne ... pas is the formal and standard choice, while the simple postverbal marker pas is the spoken colloquial option. In (standard) Catalan, quite differently, the preverbal element no is obligatory, and a post-verbal pas [pas] may follow the verb, and often does, but it adds a pragmatic "emphasis" to the utterance, which (this time simplifying considerably) makes it adequate, for instance, in utterances which run counter the expectations of the hearer (cf. GLC 2016: 1309-1310). So the no and no...pas constructions are not equivalent and interchangeable in Catalan, although they may be present in the same speech register. Notice that the (especially northern) Italian construction non ... mica seems to work very much like Catalan no....pas, but is not taken into account, given that Italian is assigned NegV value in Map 143A.

Point (ii) is also considered in Map 143A by means of a separate, mixed NegV/VNeg value, assigned for instance to German, whose sentence negator nicht is postverbal in main clauses, but preverbal in most subordinate clauses ${ }^{14}$. Point (iii) is more delicate from a typological point of view and has also some import in the Romance domain. Taking spoken French, for instance, the unique marker pas is usually characterized as postverbal. The data are not so straightforward, however, because pas follows finite verb forms only: je fais pas ça, 'I don't do that' but pour pas faire ça 'in order not to do that', j'ai pas fait ça 'I have not done that'. The same happens with most (but not all; see e.g. Milanese below) Romance languages possessing what are usually simply called postverbal negators: e.g. Sursilvan Jeu hai buc fatg quei, Turinese [i 1 ai 'nen fait 'loy] 'I have not done that'. This is not a minor issue, because, even leaving out infinitives, the compound forms constitute about half of the Romance active verb paradigms, plus all passive forms. To assign a positional value for negators in such languages, it becomes then crucial which form is taken as the verb. Dahl (1979: 91), in the first large-scale typological study of negation, was very clear in taking the "finite element" as the point of reference. In his approach, Sursilvan or Turinese would then feature rather neatly as VNeg languages (treating the constructions with the infinitive as marginal exceptions to the main pattern). Sursilvan is indeed so treated in Map 143A. Unfortunately, Dryer (2013c)'s approach, clearly stated in the accompanying text, is just the opposite: he takes the main verb as reference point, his most convincing argument being that reliable crosslinguistic criteria for finiteness are hard to find, while the verbal item carrying the main semantic content is always identifiable. Moreover, when the negator is the auxiliary itself

\footnotetext{
${ }^{14}$ However, the reason for assigning the mixed NegV/VNeg value to German is not stated explicitly in Dryer (2013c) and may also be related to the fact that Neg precedes the main verb also in main clauses when auxiliaries are present, as discussed for Danish under point (iii).
} 
(as in Finnish), and not a "particle", its position necessarily has to be computed with respect to the main (non-finite) verb.

Therefore, Dryer (2013c) explicitly explains his assignment of Danish to the mixed type $\mathrm{NegV/VNeg}$ with the immediately post-auxiliary syntax of its negator $i k k e$. The examples given

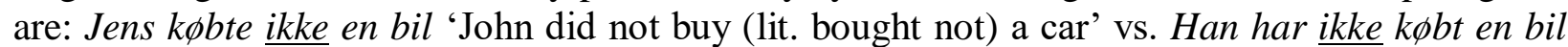
'he has not bought a car'. In fact, the choice of this language to illustrate the point is not felicitous, because Danish is like German, in that the negator ikke also precedes any simple main verb in subordinate clauses and follows it in main clauses (Allan, Holmes \& Lundskær-Nielsen 2000: 156; 167), which would probably be a sufficient reason to assign the language to the mixed type irrespective of how compound verbs are treated. Despite being somehow counterintuitive, by mixing very different situations under the same label, Dryer's choice has its motivations; however, if applied consistently, Sursilvan (and Turinese, if it were present in the sample) should not be assigned VNeg, but rather the same mixed value NegV/VNeg.

A third procedure, which would enable us to separate German-like phenomena from cases like Sursilvan, would be perhaps advisable. One could consider that for typological purposes it is always necessary to extract information, among the great amount of data available from a given language, from that subset which can be taken somehow as prototypical: in particular, to privilege, whenever possible, structurally simpler constructions in order to ease the task of crosslinguistic comparability. Therefore, investigating the ordering properties of sentential negation at a typological level, it could be safer to restrict the database for every language to those declarative sentences displaying just one verb-like unit carrying all the semantic and grammatical content (cf. the similar approach suggested in Haspelmath 2011 concerning alignment typology). By this reasoning, languages like Sursilvan would be VNeg independently from any stance about auxiliaries, because sentences with compound verbs would not be taken as a basis for cross-linguistic comparison anyway. However, while feasible with both particle-like and affixal negation, this procedure would offer no straightforward solution to compare them with negative auxiliaries: one should consider, as Dahl (1979) practically does, the position of the negative auxiliary with respect to the lexeme which acts as a finite element in the corresponding positive sentence.

At any rate, the reader might wonder if any Romance language exists which falls under the type VNeg also in the restrictive sense defended by Dryer (2013c). The answer is in the positive, having again recourse to the fertile terrain of Italo-Romance varieties. In Milanese, the postverbal negator [no] obligatorily occurs after the whole sequence auxiliary-main verb: [u vist 'no la 'tuza] 'I have not seen the girl' (Zanuttini 1997: 88). Another such variety, with the negator não at the very end of the clause, is Brazilian Portuguese (cf. Schwegler 1991), but in this case the preverbal negator (which is não as well) may also be present, so in Dryer's terms it would rather count as another instance of "optional double negation".

Finally, a further value not occurring in WALS's 8-languages Romance subsample, but easily found in northern Italo-Romance, is "obligatory double negation": most Emilian varieties are such (the main types are [n] ... ['mi(g)a] and [n] ... ['briza]), while some other varieties in this region would probably better feature under "optional double negation". For any details about the variegated situation displayed by northern Italo-Romance on the whole, the reader is referred to Zanuttini (1997) and Parry (1996; 2013).

As a conclusion, concerning the positional typology of negators, the eight Romance languages considered in WALS already give a picture of diversity, featuring three different values, although some assignments are questionable in detail. But the real diversity is in fact greater, and 
covers all the five values of Dryer's typology which include syntactic negation only (there are several other types, which however involve affixal negators or a mixture of the two strategies).

It is fair to say that the linear ordering of negation is surely an exceedingly complex affair to describe at the typological level: one reason could be the very high diachronic instability of negation. Romance is an obvious example, given that Latin had a simple, typologically unmarked syntactic NegV strategy, and a wider picture can be found in Willis et al. (2013), and in Mosegaard Hansen \& Visconti (2014).

The instability concerns structures but forms as well, as is typically shown by the well-known Jespersen's cycle (Jespersen 1917: 4, but so named only after Dahl 1979: 88; among the huge subsequent literature see, for instance, Schwegler 1988, van der Auwera 2009, Breitbarth et al. 2020). The many Romance varieties which have developed and grammaticalized a VNeg type, starting from constructions in which an item was added postverbally to the original negator to convey some pragmatically marked content, have had recourse to very varied lexical sources, even in contiguous areas. Three main groups can be identified: (i) the negative quantifier 'nothing', as in Piedmontese [nєn], Badiot Ladin ['nia]; (ii) lexical items originally denoting minimal quantities, as in French pas (<'step'), East Lombard ['mia] (<'crumb'), Sursilvan [buk] (<'morsel'), Bolognese ['briza] (<'crumb'); and (iii) expressions of holophrastic negation originally occurring sentence-finally (Milanese [no], Brazilian Portuguese não).

This diversity in lexical sources, even coming from different parts of speech, is partially responsible for the subtle differences in syntax within the macro-category of postverbal negation, which cannot be fully captured in any typologically-oriented approach, but have been the subject of much work (for a survey, see Poletto 2016 and references therein). This is not to say that the three lexical sources listed above correlate rigidly with a given synchronic syntax: although each of the three clearly has its own preferential syntax across Romance, there are also several exceptions, presumably due to contact with neighbouring varieties, change in pragmatic function etc.

Beyond the familiar pattern of Jespersen's cycle, much rarer instances of renewal are also found in the preverbal negator: a particularly interesting one is Sicilian neca (still a pragmatically marked negator, however: see Garzonio \& Poletto 2015: 140-142), because, being traceable back to a negative existential construction (neca < un jè ca 'it is not that'), it offers a Romance contribution to another typologically debated diachronic cycle of negation, usually called "Croft's cycle" (Croft 1991; Veselinova 2014).

A different typological perspective on sentence negation is taken in Miestamo (2005), reflected in the WALS maps 113, 114. Its main defining parameter is the dichotomy between "symmetric" and "asymmetric" negation. The negative construction is labelled symmetric if it does not differ from the corresponding affirmative in any other meaningful way than by the presence of negative markers (Miestamo 2005: 61). On the whole, despite the relevant functional motivations for the different kinds of asymmetric negation, symmetric negation turns out to be the most widespread type in Miestamo's balanced language sample, which deals with main declarative sentences only.

With respect to this parameter, Romance languages are essentially uniform, as they all display the symmetric type in declarative sentences, like their common ancestor. The important changes and diversification of the negative construction in both form and syntax have had absolutely no effect on the parameter of symmetricity. However, asymmetry is interestingly present in imperative sentences, especially in the second person singular. Here Romance is not uniform at all: besides languages like French, in which also the imperative is fully symmetrical (compare parle! 'speak!' and ne parle pas! 'don't speak!', where the same verb form is used for the 
positive and the negative imperative, or "prohibitive"), there are various asymmetric strategies (several examples in Poletto 2016: 840-841), where the prohibitive is expressed by the usual negation plus the infinitive (Italian, Romanian), the subjunctive (Spanish, Portuguese, Catalan, Sardinian) or even a construction with a dedicated auxiliary (several Italo-Romance varieties, especially in Liguria, Veneto and Puglia). WALS Map 71 (van der Auwera \& Lejeune 2013) shows that typologically imperatives are a favourite locus for asymmetry, but more often than not, the asymmetry in the verb form is also accompanied by a dedicated negative marker. A specialized negative marker for imperatives is very rare in Romance, although it is attested, both in combination with the same verb form used in the positive (Badiot Ladin uses the negative marker no in imperatives only, cf. Poletto \& Zanuttini 2003, Salvi 2016: 163) and with an asymmetric construction (Bolognese uses ['briza] alone, and in preverbal position, plus the infinitive form as in Italian, while in the indicative the double negator [n] . .. ['briza] occurs, cf. Parry 2013: 105). Thus, in this case, an accurate inspection of Romance varieties would provide again instances of all four values of van der Auwera \& Lejeune's (2013) proposed typology for prohibitives, but it is also clear that the two alternatives with specialized negator - very frequent at the world's level and even present within Europe - are definitely marginal in Romance, and could be seen as transitional phases in a domain like negation, where the speed of structural change is demonstrably very high (presumably due to the relevant import of pragmatic-aimed reinforcing strategies, which provide a constant source for the renewal of forms and constructions). A methodological caveat is then in order here, of the opposite nature with respect to what has been generally highlighted in this article: when aiming at characterizing typologically a given language family, although looking to capture the maximum of internal diversity, it is perhaps advisable to exercise some restraint in giving equal relevance to very marginal, localized and possibly unstable cases.

\section{References}

Aissen, J. (2003). Differential object marking: iconicity vs. economy. Natural Language and Linguistic Theory, 21, 435-448.

Allan, R., Holmes, Ph. \& Lundskær-Nielsen, T. (2000). Danish: An essential grammar. London: Routledge.

Anderson, G. A. (2013). The velar nasal. In M. S. Dryer \& M. Haspelmath (Eds.), The world atlas of language structures online. Jena: Max Planck Institute for the Science of Human History. (Available online at http://wals.info/chapter/9. Accessed on 20/7/2020).

Anderson, S. R. (2016). Romansh (Rumantsch). In A. Ledgeway \& M. Maiden (Eds.), The Oxford guide to the Romance languages (pp. 169-184). Oxford: Oxford University Press.

Benincà, P. \& Vanelli, L. (2016). Friulian. In A. Ledgeway \& M. Maiden (Eds.), The Oxford guide to the Romance languages (pp. 139-153). Oxford: Oxford University Press.

Bossong, G. (1998). Le marquage différentiel de l'objet dans les langues d'Europe. In J. Feuillet (Ed.), Actance et valence dans les langues de l'Europe (pp. 259-295). Berlin: Mouton de Gruyter.

Breitbarth, A, Lucas, Ch. \& Willis, D. (2020). The history of negation in the languages of Europe and the Mediterranean. Vol. 2: Patterns and processes. Oxford: Oxford University Press. 
Calabrese, A. \& Wetzels, L. W. (Eds.) (2009). Loan phonology. Amsterdam \& Philadelphia: John Benjamins.

Cappellaro, C. (2016). Tonic pronominal system: Morphophonology. In A. Ledgeway \& M. Maiden (Eds.), The Oxford guide to the Romance languages (pp. 722-741). Oxford: Oxford University Press.

Company, C. (2001). Multiple dative-marking grammaticalization: Spanish as a special kind of primary object language, Studies in language 25,1, 1-47.

Croft, W. (1991). The evolution of negation. Journal of Linguistics, 27, 1-27.

Dahl, Ö. (1979). Typology of sentence negation. Linguistics, 17, 79-106.

Dressler, W. U. (2000). Subtraction. In G. Booij, Ch. Lehmann, J. Mugdan \& S. Skopeteas (Eds.), Morphology. An international handbook on inflection and word-formation. Vol.1 (pp. 581-587). Berlin: de Gruyter.

Dryer, M. S. (2013a). Coding of nominal plurality. In M. S. Dryer \& M. Haspelmath (Eds.), The world atlas of language structures online. Jena: Max Planck Institute for the Science of Human History. (Available online at http://wals.info/chapter/33. Accessed on 21/7/2020).

Dryer, M. S. (2013b). Negative morphemes. In M. S. Dryer \& M. Haspelmath (Eds.), The world atlas of language structures online. Jena: Max Planck Institute for the Science of Human History. (Available online at http://wals.info/chapter/112. Accessed on 21/7/2020).

Dryer, M. S. (2013c). Order of negative morpheme and verb. In M. S. Dryer \& M. Haspelmath (Eds.), The world atlas of language structures online. Jena: Max Planck Institute for the Science of Human History. (Available online at http://wals.info/chapter/143. Accessed on 21/7/2020).

Dryer, M. S. (2013d). Position of negative morpheme with respect to subject, object, and verb. In M. S. Dryer \& M. Haspelmath (Eds.), The world atlas of language structures online. Jena: Max Planck Institute for the Science of Human History. (Available online at http://wals.info/chapter/144. Accessed on 21/7/2020).

Dryer, M. S. \& Haspelmath, M. (Eds.) (2013). The world atlas of language structures online. Jena: Max Planck Institute for the Science of Human History. (Available online at https://wals.info).

Fiorentino, G. (2003). Romance objects: Transitivity in Romance languages. Berlin: Mouton de Gruyter.

Garzonio, J. \& Poletto, C. (2015). On preverbal negation in Sicilian and syntactic parasitism. Isogloss, 1, 133-149.

GLC = Institut d'Estudis Catalans (2016), Gramàtica de la llengua catalana. Barcelona: Institut d'Estudis Catalans.

Haiman, J. \& Benincà, P. (1992). The Rhaeto-Romance Languages. London: Routledge.

Hajek, J. (2013). Vowel nasalization. In M. S. Dryer \& M. Haspelmath (Eds.), The world atlas of language structures online. Jena: Max Planck Institute for the Science of Human History. (Available online at http://wals.info/chapter/10. Accessed on 20/7/2020).

Haspelmath, M. (2011). On S, A, P, T, and R as comparative concepts for alignment typology. Linguistic Typology 15, 3, 535-567. 
Haspelmath, M. (2013a). Occurrence of Nominal Plurality. In M. S. Dryer \& M. Haspelmath (Eds.), The world atlas of language structures online. Jena: Max Planck Institute for the Science of Human History. (Available online at http://wals.info/chapter/34. Accessed on 21/7/2020).

Haspelmath, M. (2013b). Negative indefinite pronouns and predicate negation. In M. S. Dryer \& M. Haspelmath (Eds.), The world atlas of language structures online. Jena: Max Planck Institute for the Science of Human History. (Available online at http://wals.info/chapter/115. Accessed on 21/7/2020).

Iemmolo, G. (2010). Topicality and differential object marking: Evidence from Romance and beyond. Studies in Language, 34, 2, 239-272.

Jespersen, O. (1917). Negation in English and other languages. Copenhagen: Høst.

Kortmann, B. (Ed.) (2004). Dialectology meets typology. Berlin: Mouton de Gruyter.

Ledgeway, A. (2009). Grammatica diacronica del napoletano. Tübingen: Niemeyer.

Ledgeway, A. (2012). From Latin to Romance: Morphosyntactic typology and change. Oxford: Oxford University Press.

Ledgeway, A. \& Maiden, M. (Eds.) (2016). The Oxford guide to the Romance languages. Oxford: Oxford University Press.

Loporcaro, M. (2009). Opposizioni di caso nel pronome personale: i dialetti del mezzogiorno in prospettiva romanza, in A. De Angelis (Ed.), I dialetti italiani meridionali tra arcaismo $e$ interferenza, Atti del Convegno internazionale di Dialettologia (Messina, 4-6 giugno 2008) (pp. 207-235). Palermo: Centro di studi filologici e linguistici siciliani.

Loporcaro, M. (2011). Phonological processes. In M. Maiden, J. C. Smith \& A. Ledgeway (Eds.), The Cambridge history of the Romance languages. Volume 1: Structures (pp. 109-154). Cambridge: Cambridge University Press.

Loporcaro, M. \& Mancuso, A. (1988). Interdentale ma anche laterale: /1/ prevocalica nei dialetti della (Pre)Sila. In P. M. Bertinetto \& L. Cioni (Eds.), Unità fonetiche e fonologiche: produzione e percezione. Atti delle $8^{e}$ giornate di studio del Gruppo di Fonetica Sperimentale (A.I.A.), Pisa, 17-19 dicembre 1997 (pp. 77-90). Pisa: Scuola Normale Superiore.

Maddieson, I. (1984). Pattern of Sounds. Cambridge: Cambridge University Press.

Maddieson, I. (2013a). Consonant inventories. In M. S. Dryer \& M. Haspelmath (Eds.), The world atlas of language structures online. Jena: Max Planck Institute for the Science of Human History. (Available online at http://wals.info/chapter/1. Accessed on 20/7/2020).

Maddieson, I. (2013b). Voicing in Plosives and Fricatives. In M. S. Dryer \& M. Haspelmath (Eds.), The world atlas of language structures online. Jena: Max Planck Institute for the Science of Human History. (Available online at http://wals.info/chapter/4. Accessed on 20/7/2020).

Maddieson, I. (2013c). Voicing and Gaps in Plosive Systems. In M. S. Dryer \& M. Haspelmath (Eds.), The world atlas of language structures online. Jena: Max Planck Institute for the Science of Human History. (Available online at http://wals.info/chapter/5. Accessed on 20/7/2020).

Maddieson, I. (2013d). Vowel Quality Inventories. In M. S. Dryer \& M. Haspelmath (Eds.), The world atlas of language structures online. Jena: Max Planck Institute for the Science of Human History. (Available online at http://wals.info/chapter/2. Accessed on 20/7/2020). 
Maddieson, I. (2013e). Uvular consonants. In M. S. Dryer \& M. Haspelmath (Eds.), The world atlas of language structures online. Jena: Max Planck Institute for the Science of Human History. (Available online at http://wals.info/chapter/6. Accessed on 20/7/2020).

Maddieson, I. (2013f). Glottalized consonants. In M. S. Dryer \& M. Haspelmath (Eds.), The world atlas of language structures online. Jena: Max Planck Institute for the Science of Human History. (Available online at http://wals.info/chapter/7. Accessed on 20/7/2020).

Maddieson, I. (2013g). Lateral consonants. In M. S. Dryer \& M. Haspelmath (Eds.), The world atlas of language structures online. Jena: Max Planck Institute for the Science of Human History. (Available online at http://wals.info/chapter/8. Accessed on 20/7/2020).

Maddieson, I. (2013h). Front rounded vowels. In M. S. Dryer \& M. Haspelmath (Eds.), The world atlas of language structures online. Jena: Max Planck Institute for the Science of Human History. (Available online at http://wals.info/chapter/11. Accessed on 20/7/2020).

Maddieson, I. (2013i). Presence of uncommon consonants. In M. S. Dryer \& M. Haspelmath (Eds.), The world atlas of language structures online. Jena: Max Planck Institute for the Science of Human History. (Available online at http://wals.info/chapter/19. Accessed on 20/7/2020).

Maiden, M. (1996). On the Romance inflectional endings - $i$ and -e. Romance Philology, 50, 147182.

Maiden, M. (2016). Romanian. Istro-Romanian, Megleno-Romanian, and Aromanian. In A. Ledgeway \& M. Maiden (Eds.), The Oxford guide to the Romance languages (pp. 91-125). Oxford: Oxford University Press.

Maiden, M. \& Parry, M. (Eds.) (1997). The dialects of Italy. London: Routledge.

Mensching, G. \& Remberger, E. M. (2016). Sardinian. In A. Ledgeway \& M. Maiden (Eds.), The Oxford guide to the Romance languages (pp. 270-291). Oxford: Oxford University Press.

Miestamo, M. (2005). Standard negation: The negation of declarative verbal main clauses in a typological perspective. Berlin: Mouton de Gruyter.

Miestamo, M. (2013a). Symmetric and asymmetric standard negation. In M. S. Dryer \& M. Haspelmath (Eds.), The world atlas of language structures online. Jena: Max Planck Institute for the Science of Human History. (Available online at http://wals.info/chapter/113. Accessed on 21/7/2020).

Miestamo, M. (2013b). Subtypes of asymmetric standard negation. In M. S. Dryer \& M. Haspelmath (Eds.), The world atlas of language structures online. Jena: Max Planck Institute for the Science of Human History. (Available online at http://wals.info/chapter/114. Accessed on 21/7/2020).

Mosegaard Hansen, M.-B. \& Visconti, J. (Eds.) (2014). The diachrony of negation. Amsterdam: Benjamins.

Murelli, A. \& Kortmann, B. (2011). Non-standard varieties in the areal typology of Europe. In B. Kortmann \& J. Van der Auwera (Eds.), The languages and linguistics of Europe: A comprehensive guide (pp. 525-544). Berlin: De Gruyter Mouton.

Nedelcu, I. (2013). Prepositions and prepositional phrases. In G. Pană Dindelegan (Ed.), The grammar of Romanian (pp. 451-465). Oxford: Oxford University Press.

Nichols, J. (1986). Head-marking and dependent-marking grammar. Language, 62, 56-119. 
Nichols, J. \& Bickel, B. (2013a). Locus of marking in the clause. In M. S. Dryer \& M. Haspelmath (Eds.), The world atlas of language structures online. Jena: Max Planck Institute for the Science of Human History. (Available online at http://wals.info/chapter/23. Accessed on 22/7/2020).

Nichols, J. \& Bickel, B. (2013b). Locus of marking in possessive noun phrases. In M. S. Dryer \& M. Haspelmath (Eds.), The world atlas of language structures online. Jena: Max Planck Institute for the Science of Human History. (Available online at http://wals.info/chapter/24. Accessed on 22/7/2020).

Nichols, J. \& Bickel, B. (2013c). Locus of marking: Whole-language typology. In M. S. Dryer \& M. Haspelmath (Eds.), The world atlas of language structures online. Jena: Max Planck Institute for the Science of Human History. (Available online at http://wals.info/chapter/25. Accessed on 22/7/2020).

Nicoli, F. (1983). Grammatica milanese. Busto Arsizio: Bramante.

Oliviéri, M. \& Sauzet, P. (2016). In A. Ledgeway \& M. Maiden (Eds.), The Oxford guide to the Romance languages (pp. 319-349). Oxford: Oxford University Press.

Pană Dindelegan, G. (2013a). The direct object. In G. Pană Dindelegan (Ed.), The grammar of Romanian (pp. 125-144). Oxford: Oxford University Press.

Pană Dindelegan, G. (Ed.) (2013b). The grammar of Romanian. Oxford: Oxford University Press.

Parry, M. (1996). La negazione italo-romanza: Variazione tipologica e variazione strutturale. In P. Benincà, G. Cinque, T. De Mauro \& N. Vincent (Eds.), Italiano e dialetti nel tempo: Saggi di grammatica per Giulio C. Lepschy, (pp. 225-257). Roma: Bulzoni.

Parry, M. (1997). Piedmont. In M. Maiden \& M. Parry, (Eds.), The dialects of Italy (pp. 237244). London: Routledge.

Parry, M. (2013). Negation in the history of Italo-Romance. In D. Willis, Ch. Lucas \& A. Breitbarth, (Eds.), The history of negation in the languages of Europe and the Mediterranean. Vol. 1: Case Studies (pp. 77-118). Oxford: Oxford University Press.

Penny, R. (2000). Variation and change in Spanish. Cambridge: Cambridge University Press.

Poletto, C. (1997). Pronominal syntax. In M. Maiden \& M. Parry, (Eds.), The dialects of Italy (pp. 137-144). London: Routledge.

Poletto, C. (2016). Negation. In A. Ledgeway \& M. Maiden (Eds.), The Oxford guide to the Romance languages (pp. 833-846). Oxford: Oxford University Press.

Poletto, C. \& Zanuttini, R. (2003). Making imperatives: Evidence from central Rhaetoromance. In Ch. Tortora (Ed.), The syntax of Italian dialects, 175-206. Oxford: Oxford University Press.

Salvi, G. (2016). Ladin. In A. Ledgeway \& M. Maiden (Eds.), The Oxford guide to the Romance languages (pp. 154-168). Oxford: Oxford University Press.

Sampson, R. (2016). Sandhi phenomena. In A. Ledgeway \& M. Maiden (Eds.), The Oxford guide to the Romance languages (pp. 669-680). Oxford: Oxford University Press.

Savoia, L. \& Maiden, M. (1997). Metaphony. In M. Maiden \& M. Parry, (Eds.), The dialects of Italy (pp. 11-25). London: Routledge. 
Schmid, S. (1999). Per un'analisi del vocalismo italiano in chiave tipologica. In P. Benincà, A. Mioni \& L. Vanelli (Eds.), Fonologia e morfologia dell'italiano e dei dialetti d'Italia. Atti del XXXI Congresso internazionale di studi della Società di Linguistica Italiana (pp. 505-538). Roma: Bulzoni.

Schmid, S. (2016). Segmental Phonology. In A. Ledgeway \& M. Maiden (Eds.), The Oxford guide to the Romance languages (pp. 471-483). Oxford: Oxford University Press.

Schwegler, A. (1988). Word-order changes in predicate negation strategies in Romance languages. Diachronica 5, 21-58.

Schwegler, A. (1991). Predicate negation in contemporary Brazilian Portuguese: A change in progress. Orbis, 34, 187-214.

Smith, J. C. (2016). French and northern Gallo-Romance. In A. Ledgeway \& M. Maiden (Eds.), The Oxford guide to the Romance languages (pp. 292-318). Oxford: Oxford University Press.

Stan, C. (2013a). Phonological and orthographic features of Romanian. In G. Pană Dindelegan (Ed.), The grammar of Romanian (pp. 7-17). Oxford: Oxford University Press.

Stan, C. (2013b). Inflectional and derivational morphophonological alternations. In G. Pană Dindelegan (Ed.), The grammar of Romanian (pp. 607-611). Oxford: Oxford University Press.

van der Auwera, J. (2009). The Jespersen cycles. In E. van Gelderen (Ed.), Cyclical Change (pp. 35-71). Amsterdam: Benjamins.

van der Auwera, J. \& Lejeune, L. (with V. Goussev) (2013). The Prohibitive. In M. S. Dryer \& M. Haspelmath (Eds.), The world atlas of language structures online. Jena: Max Planck Institute for the Science of Human History. (Available online at http://wals.info/chapter/71. Accessed on 21/7/2020).

Veselinova, L. (2014). The negative existential cycle revisited. Linguistics, 52, 6, 1327-1389.

Vincent, N. (1997). The emergence of the D-system in Romance. In A. van Kemenade \& N. Vincent (Eds.), Parameters of morphosyntactic change (pp. 149-169). Cambridge: Cambridge University Press.

Weiss, M. (2009). Outline of the historical and comparative grammar of Latin. Ann Arbor: Beech Stave Press.

Willis, D., Lucas, Ch. \& Breitbarth, A. (Eds.). (2013). The history of negation in the languages of Europe and the Mediterranean. Vol. 1: Case studies. Oxford: Oxford University Press.

Zanuttini, R. (1997). Negation and clausal structure: A comparative study of Romance languages. Oxford: Oxford University Press.

Zörner, L. (1989). Die Dialekte von Travo und Groppallo. Wien: Verlag der österreichischen Akademie der Wissenschaften. 